\title{
Improving Measures Analysis on the Fusion Development of Chongqing Higher Vocational Education and Local Industries
}

\author{
Runjuan Li \\ Chongqing Technology and Business University \\ Chongqing, China 400070
}

\author{
Shuaijin Huang \\ Chongqing Technology and Business University \\ Chongqing, China 400070
}

\author{
Youxin Liu* \\ Chongqing Jianzhu College \\ Chongqing, China 400070 \\ *Corresponding Author
}

\begin{abstract}
Based on the analysis of the trends of the relation between the investment in higher vocational education (HVE) and economic growth, this paper analyzes and points out the prominent problems in the development of HVE in Chongqing, and then the authors put forward some improving measures through the integration of education and industries, mainly by strengthening the cooperation of schools, enterprises and governments, matching professional settings with industrial structure, adjusting the distributions of schools and their specialties according to different regional functional orientations, and optimizing the operating mechanism of HVE funds.
\end{abstract}

Keywords - higher vocational education (HVE); integration of education and industries; input mechanism

\section{INTRODUCTION}

Chongqing, located in the upstream of the Yangtze River, is the only municipality in the western region. In recent years, the quality and efficiency of economic growth has been steadily improved, and employment, resident income and price index are in good condition. The sustained and stable growth of economy in Chongqing mainly benefits from the constant structural reform of the supply side. At the same time, the sustained and sound development of the economy is inseparable from the support of talents, and higher vocational education as an important part of education system in Chongqing, is the important basis of personnel training, achievement transformation and technical application. The rapid adjustment of industrial structure, the rapid development of new industries and the constant advancement of new industrialization and new rural construction in Chongqing objectively put forward higher requirements for higher vocational education in Chongqing. Based on the analysis of the development situation of

Fund Project: Chongqing Social Science Planning Project: research on the strengthening of integration of higher vocational education and economic development (2012YBJJ038). economy, industry and higher vocational education in Chongqing and their relationship, this paper puts forward some suggestions on promoting the fusion development of higher vocational education and industry in Chongqing aiming at the prominent problems.

\section{AN ANALYSIS OF THE CURRENT DEVELOPMENT OF Higher VocATIONAL EDUCATION IN CHONGQING}

After experiencing the rapid development stage, Chongqing higher vocational education began to enter a connotative development period to comprehensively improve the quality of education and teaching and pay attention to the benefit. Up to early 2017, there are totally 41 higher vocational (junior college) institutions in Chongqing City as shown in "Table 1", accounting for about $60 \%$ of the total number of institutions of higher learning. Among the higher vocational (junior college) institutions, there are 22 public institutions, and 19 private colleges. 


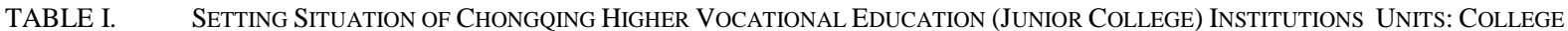

\begin{tabular}{|c|c|c|}
\hline Chongqing Electric Power College & Chongqing Three Gorges Medical College & Chongqing Medical and Pharmaceutical College \\
\hline Chongqing Preschool Education College & $\begin{array}{l}\text { Chongqing Aerospace } \quad \text { Polytechnic } \\
\text { College }\end{array}$ & Chongqing College of Electronic Engineering \\
\hline Chongqing Industry Polytechnic College & Chongqing City Management College & Chongqing Vocational Institute \\
\hline Chongqing Technology \& Business Institute & $\begin{array}{l}\text { Chongqing Three Gorges Polytechnic } \\
\text { College }\end{array}$ & Chongqing Industry \& Trade Polytechnic \\
\hline $\begin{array}{l}\text { Chongqing Water Resources and Electric Engineering } \\
\text { College }\end{array}$ & Chongqing City Vocational College & Chongqing Youth Vocational \& Technical College \\
\hline Chongqing College of Finance Economics & Chongqing Jianzhu College & Chongqing Business Vocational College \\
\hline Chongqing Haili & Chongqing Real Estate College & Chongqing Electromechanical Vocational Institute \\
\hline Chongqing Vocational College of Applied Technology & Chongqing Creation Vocational College & $\begin{array}{l}\text { Chongqing Telecommunication } \quad \text { Polytechnic } \\
\text { College }\end{array}$ \\
\hline Chongqing Energy College & $\begin{array}{l}\text { Chongqing Vocational } \\
\text { Transportation }\end{array}$ & $\begin{array}{l}\text { Chongqing Vocational College of } \\
\text { Transportation }\end{array}$ \\
\hline Chongqing Vocational College of Art \& Engineering & $\begin{array}{l}\text { Chongqing Vocational college of Light } \\
\text { Industry }\end{array}$ & Chongqing Telecommunications College \\
\hline
\end{tabular}

a. Data Source: "list of Vocational Colleges in Chongqing in 2016" published by Chongqing Education Commission in Chongqing Vocational and Technical Education website.

\section{A. The Number of Students in Higher Vocational Colleges Increases Rapidly}

In recent years, the number of undergraduates, graduates and enrollment of higher vocational colleges in Chongqing shows a rising trend as in "Fig. 1". According to the data from "China Education Statistics Yearbook in 2016", the total number of undergraduates in higher vocational education in Chongqing reached 273,200 people in 2015, the total number of graduates reached 81,300 people, and number of enrollment reached 10.13 million. Compared with 2014, the number of undergraduates increased by 1.5 million, the number of graduates increased by 79,900 , and the number of enrollment increased by 10,200 people.

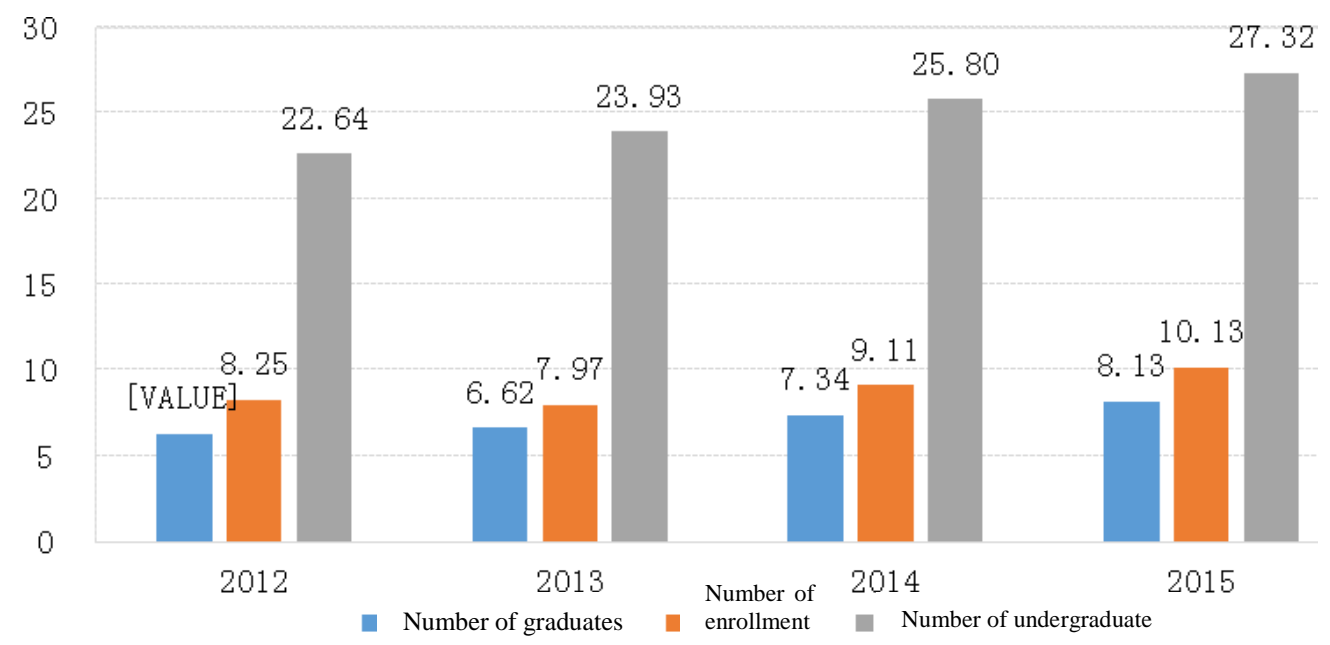

Fig. 1. Changing Situation of the Number of Undergraduates, Graduates and Enrollment in Higher Vocational College in 2012-2015.

\section{B. The Number of Full-time Teachers is Growing Slowly}

The total number of faculty and staff in Chongqing higher vocational school increased from 15,241 in 2012 to 17075 in 2015, with an increase of 1834 in three years; the number of full-time teachers increased from 10,484 in 2012 to 12,341 in 2015 , with an increase of 1857 in three years; b. Data source: the table "18-6 development situation of education" of "Chongqing Statistical Yearbook" in 2013-2016 the proportion of full-time teachers in the total number of staff increased from $68.8 \%$ in 2012 to $72.3 \%$ in 2015 , an increase of $3.5 \%$ over three years. Although the total amount of teachers has been increasing and the structure has been optimized as in "Fig. 2", the growth rate of number of teachers is relatively slow. 


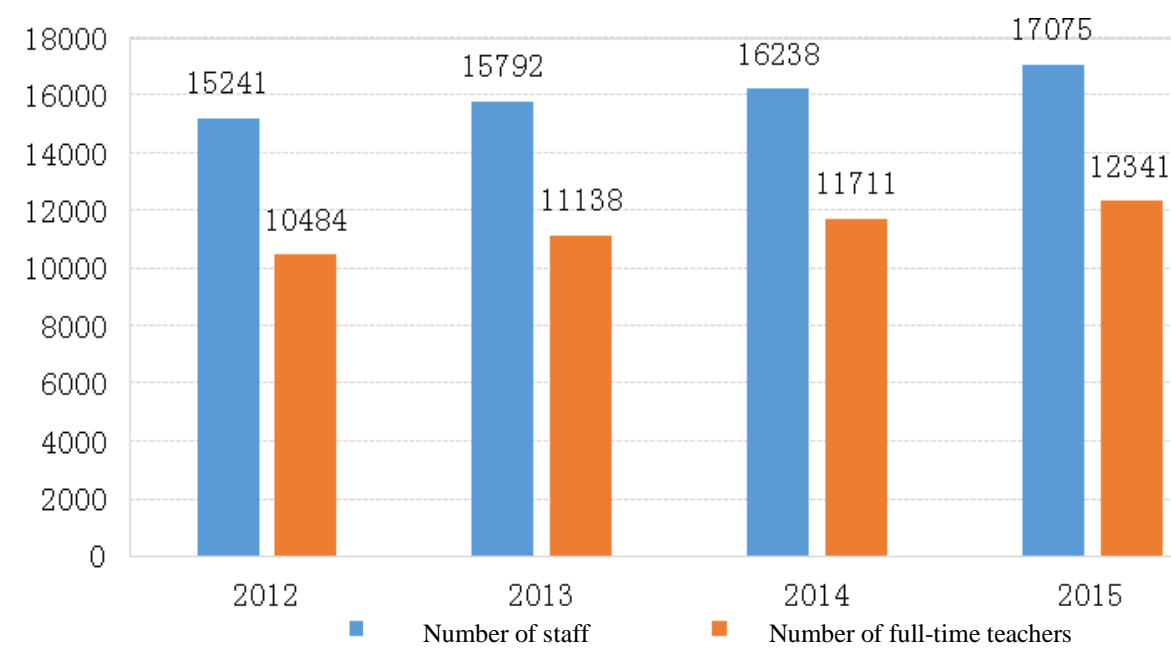

Fig. 2. Changing situation of teachers in higher vocational colleges in 2012-2015.

\section{Student-teacher Ratio Slightly Increases}

The data presented in "Table 2" show that, in recent years, with the scale expansion and rapid development of Chongqing higher vocational colleges, although the number of full-time teachers increased, the growth rate of the number of undergraduates is significantly higher than that of fulltime teachers. The student-teacher ratio has increased slightly from 21.59: 1 in 2012 to $22.14: 1$ in 2015 , which brings sustainable challenges to the improvement of the teaching quality and development of connotation.

TABLE II. CHANGE IN STUDENT-TEACHER RATIO IN CHONGQING Higher VocATIONAL COLLEGES IN 2012-2015

\begin{tabular}{cccc}
\hline Year & $\begin{array}{c}\text { Number of } \\
\text { undergraduates }\end{array}$ & $\begin{array}{c}\text { Number of full- } \\
\text { time teachers }\end{array}$ & $\begin{array}{c}\text { Student- } \\
\text { teacher ratio }\end{array}$ \\
\hline 2012 & 226356 & 10484 & 21.59 \\
2013 & 239271 & 11138 & 21.48 \\
2014 & 257969 & 11711 & 22.03 \\
2015 & 273178 & 12341 & 22.14 \\
\hline \multicolumn{2}{c}{ d. Data source: the table "18-6 development situation of education" of "Chongqing Statistical } \\
\multicolumn{2}{c}{ Yearbook" in 2013-2016. }
\end{tabular}

\section{THE PROMOTING ROLE OF INVESTMENT IN \\ CHONGQING HIGHER VOCATIONAL EDUCATION FOR ECONOMIC GROWTH IS OBVIOUS}

Economic development needs to be measured by multiple indicators, in which economic growth is the most representative and most commonly used indicator of economic development. Based on this, this study intends to use gray correlation analysis method and elastic coefficient method to analyze the promoting role of Chongqing higher vocational education for economic growth. First of all, the relationship between higher vocational education and economic growth in Chongqing can be grasped overall through the grey correlation model, and then the response of economic growth in Chongqing to higher vocational education and its changes over time can be analyzed through
Data source: the table "18-6 development situation of education" of "Chongqing Statistical Yearbook" in 2013-2016 the elastic coefficient of economic growth in Chongqing on the development of higher vocational education.

\section{A. Introduction to the Based Model Method}

1) Gray correlation Model: The gray correlation (or gray correlation coefficient) mainly describes the degree of consistency of the trend of one sequence compared with another. Different gray correlation degree has different algorithm. Here only the algorithm of Deng's correlation degree is introduced:

- Define the reference sequence (dependent variable sequence) as $X_{n}=\left(x_{01}, x_{02}, \cdots, x_{0 j}\right)$, the comparison sequence (independent sequence) as $X_{i}=\left(x_{i 1}, x_{i 2}, \cdots, x_{i j}\right)$, where $j=1,2, \cdots m, \mathrm{~m}$ represents the sequence length, and $i=1,2, \cdots, n, \mathrm{n}$ is the number of comparison sequences.

- Standardize the data. Here we use the averaging method to standardize the data as follows:

$X_{0}^{\prime}=X_{0} / \bar{x}_{0}=\left(x_{01}^{\prime}, x_{02}^{\prime}, \cdots, x_{0 j}^{\prime}\right)$

$X_{i}^{\prime}=X_{i} / \bar{x}_{i}=\left(x_{i 1}^{\prime}, x_{i 2}^{\prime}, \cdots, x_{i j}^{\prime}\right)$, in which $\bar{x}_{0}$ and $\bar{x}_{i}$ are the mean values of sequence $X_{0}$ and $X_{i}$ respectively.

- Find the difference sequence and take the maximum and minimum values from the sequence values of all the difference sequences [2].

The difference sequence is: $X_{0 i}=\left(\left|x_{01}^{\prime}-x_{i 1}^{\prime}\right|,\left|x_{02}^{\prime}-x_{i 2}^{\prime}\right|, \cdots,\left|x_{0 j}^{\prime}-x_{i j}^{\prime}\right|\right)=\left(\Delta_{i 1}, \Delta_{i 2}, \cdots, \Delta_{i j}\right)$

The maximum value is: $M=\max \left(\Delta_{i 1}, \Delta_{i 2}, \cdots, \Delta_{i j}\right)$

The minimum is: $m=\min \left(\Delta_{i 1}, \Delta_{i 2}, \cdots, \Delta_{i j}\right)$

- Calculate the correlation coefficient sequence.

$R_{i}=(m+\delta M) /\left(X_{0 i}+\delta M\right)=\left\{R_{i 1}, R_{i 2}, \cdots, R_{i n}\right\}$ 
- Calculate the degree of correlation.

$$
r_{i}=\frac{1}{m} \sum_{j=1}^{m} R_{i j}, i=1,2, \cdots, n .
$$

2) Elasticity coefficient: The elasticity coefficient is the percentage of the corresponding change of another correlated variable when a variable is changed by a certain percentage, indicating the dependence relationship between the two variables [3]. In this study, the elastic coefficient of economic growth in Chongqing to the development of higher vocational education refers to the degree of influence of the change in the scale of investment in higher vocational education on the scale of economic output. The author takes the investment in Chongqing higher professional education (represented by E) as the index of the development scale of higher vocational education, and takes with the gross regional production of Chongqing (represented by $\mathrm{G}$ ) as the index of output scale. The elastic coefficient of economic growth to higher vocational education can be interpreted as the percentage of the change in gross regional production of Chongqing corresponding to every percentage of the change in the investment in higher vocational education.

The specific elastic coefficient of education output is as follows:

$$
\gamma_{t}=g_{t} / e_{t}
$$

Among them, $g_{t}$ is the growth rate of GRP of Chongqing in the period $\mathrm{t}$, namely $g_{t}=\left(G_{t}-G_{t-1}\right) / G_{t-1} ; e_{t}$ is the growth rate of investment in Chongqing higher vocational education in the period $\mathrm{t}$, namely $e_{t}=\left(E_{t}-E_{t-1}\right) / E_{t-1}$.

\section{B. Data Selection and Processing}

The relationship between the scale of Chongqing higher vocational education (E) and the economic growth $(\mathrm{G})$ in Chongqing is studied by selecting the two indexes of educational fund investment in Chongqing higher vocational schools from 2005 to 2015 and the GRP of Chongqing. However, due to the fact that part of the educational funds investment over the years will form fixed assets, of which the total stock will play a role in economic growth for a long period of time. Therefore, obviously we cannot only use the flow indicator of educational funds investment in higher vocational school in one certain year to study its relationship with economic growth.

We use the fixed asset investment price index taking 2005 as the base period to adjust the gross fixed assets of higher vocational schools at the end of the year higher, to represent the fixed assets stock. And then "equipment purchase costs, repair charge and infrastructure spending" are excluded from the educational funds investment in higher vocational schools over the years, serving as the educational funds investment without fixed assets (adjusted by the CPI index with 2005 as the base period). The "actual investment" of educational fund of higher vocational school over the years can be obtained by adding up the above two data. Therefore, this "actual investment" is used to represent the development scale of higher vocational education and to study its relationship with the economic growth in Chongqing (in which GRP of Chongqing is also adjusted by the GDP index with 2005 as the base period) as shown in "Table 3".

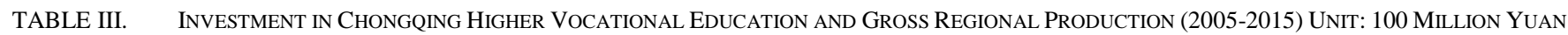

\begin{tabular}{cll|ccc}
\hline year & $\begin{array}{c}\text { higher vocational college } \\
\text { educational funds investment }\end{array}$ & $\begin{array}{c}\text { gross regional } \\
\text { production }\end{array}$ & year & $\begin{array}{c}\text { higher vocational college } \\
\text { educational funds investment }\end{array}$ & $\begin{array}{c}\text { gross regional } \\
\text { production }\end{array}$ \\
\hline 2005 & 11.87 & 3467.72 & 2011 & 60.30 & 8100.24 \\
2006 & 15.62 & 3897.66 & 2012 & 61.23 & 9201.91 \\
2007 & 19.20 & 4517.28 & 2013 & 66.04 & 10333.86 \\
2008 & 23.47 & 5172.32 & 2014 & 59.95 & 11460.16 \\
2009 & 44.32 & 5942.87 & 2015 & 74.64 & 12720.71 \\
2010 & 56.35 & 6959.05 & & & \\
\hline
\end{tabular}

e. Data source: Data from the "Comprehensive List of Educational Expenditure of Various Schools" in "Statistical Yearbook of Educational Funds in Chongqing" in corresponding years, and "Table 2-1 gross regional production (1978-2015)" in Statistical Yearbook of Chongqing in 2016

\section{Model Results and Analysis}

As the gray correlation degree is used to describe the consistent degree of the trend between the relevant sequences, the author first analyzes the situation map in "Fig. 3" of investment in Chongqing higher vocational education and GRP. 


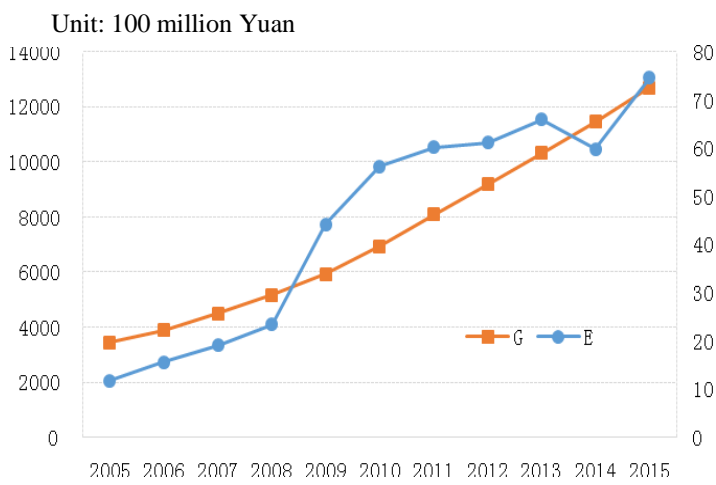

Fig. 3. Trend chart of investment in Chongqing higher vocational education and gross regional production.

f. Data source: Based on data from "Table 3"

It can be seen from "Fig. 3" that the curve of investment in Chongqing higher vocational is fluctuating around the trend of GRP, which shows that there is a close relationship between the development of Chongqing higher vocational education and economic growth, and since 2008, Chongqing's attaching importance to the development of higher vocational education has shown preliminary results.
In order to further study the changes in the degree of connection between investment in Chongqing higher vocational education and economic growth, the value of Deng's correlation degree from 2005 to 2015 is calculated in "Table 4". It can be seen that the degree of Deng's correlation in the calculated six ranges is increasing from 0.5441 to 0.5819. Especially in the period of 2009-2015, the relationship between the investment in Chongqing higher vocational education and economic growth is most close.

TABLE IV. DYNAMIC CHANGES OF DENG'S CORRELATION DEGREE BETWEEN ECONOMIC GROWTH AND HIGHER VOCATIONAL EDUCATION DEVELOPMENT IN CHONGQING

\begin{tabular}{|c|c|c|c|c|c|c|}
\hline Time span & $\begin{array}{r}2005 \\
2015\end{array}$ & $\begin{array}{r}2006- \\
2015\end{array}$ & $\begin{array}{r}2007- \\
2015\end{array}$ & $\begin{array}{r}2008- \\
2015\end{array}$ & $\begin{array}{r}2009- \\
2015\end{array}$ & $\begin{array}{r}2010 \\
2015\end{array}$ \\
\hline $\begin{array}{l}\text { Deng's } \\
\text { correlation } \\
\text { degree }\end{array}$ & 0.5441 & 0.5462 & 0.5198 & 0.4885 & 0.6604 & 0.5819 \\
\hline
\end{tabular}

g. Data Source: Calculated from the data of Table 3 according to the gray correlation model equation.

Then, according to the calculation, the elastic coefficient of the economic growth in Chongqing to the development of higher vocational education also makes note to the close relationship between the two in "Table 5".

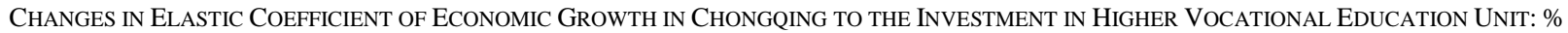

\begin{tabular}{llll}
\hline & $\begin{array}{c}\text { Investment in higher vocational education } \\
\text { Expenditure growth rate (\%) }\end{array}$ & $\begin{array}{c}\text { Gross regional production } \\
\text { Growth rate }(\mathbf{\%})\end{array}$ & $\begin{array}{c}\text { Higher vocational education } \\
\text { Elastic coefficient of output }\end{array}$ \\
\hline 2005 & - & - & - \\
2006 & 31.59 & 12.40 & 0.3925 \\
2007 & 22.93 & 15.90 & 0.6933 \\
2008 & 22.24 & 14.50 & 0.6519 \\
2009 & 88.82 & 14.90 & 0.1677 \\
2010 & 27.15 & 17.10 & 0.6299 \\
2011 & 7.01 & 16.40 & 2.3380 \\
2012 & 1.55 & 13.60 & 8.7984 \\
2013 & 7.85 & 12.30 & 1.5674 \\
2014 & -9.22 & 10.90 & -1.1826 \\
2015 & 24.50 & 11.00 & 0.4489 \\
\hline
\end{tabular}

It can be found that the growth rate of investment in higher vocational education has been maintained above $20 \%$ in 2005-2010, of which the highest is $88.82 \%$ in 2009 . Then the growth rate declined substantially during 2010 to 2014 , and even became negative growth in 2014 (-9.22\%). There are many reasons for this growth trend that rises before inhibition. The most important factor is that the 2008 global financial crisis first spread to manufacturing industry of China, resulting in a large number of coastal migrant workers losing jobs and returning home. After the economy gradually recovered in 2009, a large number of enterprises in the eastern coast and southern China are short of employees (most migrant workers are attracted by the economic growth in mainland after the return, so they won't return to the south). Therefore, serious lack of skilled workers forced the supernormal growth of higher vocational education. Therefore, 2009 is a year when higher vocational education develops prosperously.

In such context, Chongqing, with manufacturing industry as a pillar industry has also accelerated the development of h. Data Source: Calculated from the data of "Table 3".

higher vocational education. Supernormal investment needs to go through a digestion period, coupled with the existence problem of the structural surplus of higher vocational education talents, so it cannot adapt to the change in demand structure brought by industrial structure adjustment of Chongqing. With the investment in Chongqing higher vocational education gradually become rational, it regains growth trend in 2015. At the same time, GRP growth of Chongqing is relatively stable, although it first rose and then fell during 2005-2015 in the general, it always maintained above $10 \%$, showing that the strong momentum of economic growth in Chongqing opens up a lot of space for the development of higher vocational education.

In regard to the elastic coefficient of economic growth in Chongqing to investment in higher vocational education, in addition to the unconventional years after the financial crisis, the elastic coefficient of economic growth in Chongqing to investment in higher vocational education remained at around 0.5 . That is to say, increase of each $1 \%$ of investment in higher vocational education will increase the economic 
growth in Chongqing by $0.5 \%$. The too high or too low elasticity coefficient in 2011-2014 shows that the after the appearance of direct economic effect of investment in higher vocational education in short term, the long-term indirect effect is the normal of the relationship between the two.

Above all, there is a very close relationship between the development of higher vocational education and economic growth in Chongqing, which is an important driving force for economic development in Chongqing. And the particularity of education determines that along with the direct promotion to economic growth, it plays a positive role for a longer term in the quality and efficiency of economic growth.

\section{AN ANALYSIS OF THE DEVELOPMENT ISSUES OF HIGHER VOCATIONAL EDUCATION IN CHONGQING}

It must be recognized that although higher vocational education in Chongqing plays a positive role in promoting economic growth, there are still many structural problems in the development process, which seriously restrict it to play the promoting role in regional economic development, and also restraint the sound development of higher vocational education.

\section{A. Specialty Structure of Higher Vocational Colleges Can't Adapt to Industrial Restructuring in Chongqing}

The adaptability of specialty structure and local industrial structure determines the fit of talent cultivation of higher vocational education and local economic development as well as the quality and efficiency of development of higher vocational education.

The "13th Five-Year Plan" of Chongqing proposes to speed up the construction of the important modern manufacturing base in China, the domestic important functional financial center, and the western innovation center, give full play to the strategic support function of development and opening up of the west and the central hub function of the western part of the Yangtze River Economic
Zone, and basically complete the economic center in upstream of the Yangtze River [4]. The "development direction of Top Ten Strategic Emerging Industrial Clusters" proposed by the "Outline" (electronic core parts, new energy vehicles and smart cars, Internet of Things, robots and intelligent equipment, high-end traffic equipment, environmental protection industry, MDI and chemical new materials, biological medicine, new material and shale gas) points out the direction for Chongqing industrial development in next five years, and puts forward the direction of service for the development of higher vocational education in Chongqing.

Through the analysis of the fit situation between specialties of higher vocational education and the local industrial structure in Chongqing, following characteristics are founded:

First of all, specialties in some of the higher vocational colleges are repeated, resulting in employment difficulties of local graduates. By observing the specialties setting of higher vocational colleges in Chongqing, it can be found that some of the majors that have close relationship with the key industries of regional economic development in Chongqing have been blindly expanding enrollment in recent years, so some majors are in a state of excess supply to varying degrees. The authors make statistics of the record number of related specialties actually set by higher vocational colleges in Chongqing and the number of national ratified specialties and obtain the specialty coverage as shown in "Table 6" (The number of colleges that actually set the specialty / the number of national ratified specialty), which shows that the high coverage of some specialties may lead to the imbalance between supply and demand of talent, thus exacerbating the employment problem of graduates of the higher vocational colleges without distinguished features. In addition, through the analysis of enrollment specialty of Chongqing higher vocational colleges, it can be seen that more than $80 \%$ of the colleges emphasize on the specialties like finance and economics, electronic information, and arts.

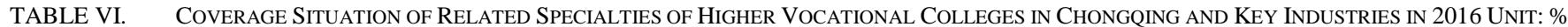

\begin{tabular}{llll}
\hline \multicolumn{1}{c}{ Specialty category } & Number of national ratified specialty & Number of actual specialty & Specialty coverage (\%) \\
\hline Electronic information & 19 & 46 & 242.1 \\
computer science & 15 & 40 & 266.7 \\
Chemical Technology & 12 & 23 & 191.7 \\
mechanical design & and & 20 & 105.3 \\
manufacturing & 19 & 59 & 842.8 \\
automobile making & 7 & 10 & 166.6 \\
urban rail transport & 6 & 22 & 314.3 \\
logistics & 7 & 21 & 525.0 \\
e-commerce & 4 & & \\
\hline
\end{tabular}

i. Data Source: arranged according to the "Higher Vocational Education (junior college) professional directory in 2016" and "higher vocational college specialty setting in Chongqing" in the system of "specialty setting

Second, most of the specialties related to the strategic emerging industries in Chongqing have the problems of the lack of setting. There is even no specialty related to biological medicine, shale gas, smart cars, high-end transport equipment, and MDI as shown in "Table 7". With the rapid development of Chongqing's economy in recent years, the industrial structure of Chongqing has been constantly adjusted and changed, and the productive service industry and the life service industry in the tertiary industry have risen rapidly. However, from the specialty setting of various schools, it can be seen that specialties related to the emerging service industry are particularly inadequate. 
TABLE VII. COVERAGE Situation OF RELEVANT SPECIALTIES OF HigHER VOCATIONAL COLLEGES IN CHONGQING AND EMERGING INDUSTRIES IN 2016 UNIT: \%

\begin{tabular}{llll}
\hline \multicolumn{1}{c}{ Specialty category } & $\begin{array}{c}\text { Number of } \\
\text { national ratified } \\
\text { specialty }\end{array}$ & $\begin{array}{c}\text { Number of } \\
\text { actual } \\
\text { specialty }\end{array}$ & $\begin{array}{c}\text { Specialty } \\
\text { coverage } \\
(\%)\end{array}$ \\
\hline $\begin{array}{l}\text { biological medicine } \\
\text { Internet of Things }\end{array}$ & 0 & 0 & 0.0 \\
$\begin{array}{l}\text { industrial robot } \\
\text { shale gas }\end{array}$ & 1 & 16 & 800.0 \\
$\begin{array}{l}\text { new } \\
\text { automobile }\end{array}$ & 0 & 9 & 900.0 \\
$\begin{array}{l}\text { smart car } \\
\text { High-end transport }\end{array}$ & 0 & 0 & 0.0 \\
$\begin{array}{l}\text { equipment } \\
\text { Environmental }\end{array}$ & 0 & 4 & 0.0 \\
$\begin{array}{l}\text { Protection } \\
\text { MDI }\end{array}$ & 11 & 0 & 0.0 \\
Materials & 0 & 0 & 0.0 \\
\hline
\end{tabular}

j. Date source: arranged according to the "Catalog of specialty of Higher Vocational Education (junior college) in 2016" and "specialty settings in Chongqing Higher Vocational College" from the system of "specialty setting record of Higher Vocational College" in the China Education

\section{B. Regional Distributions of Higher Vocational Colleges and Regional Development is not Completely Consistent}

1) The unbalanced district and county distribution of higher vocational colleges: Up to 2016, the 41 higher vocational colleges in Chongqing are mainly distributed in nine districts in the main city, with the total number of 16 . In the six central cities in Chongqing, there are 5 in Wanzhou, 5 in Jiangjin, 4 in Yongchuan, 2 in Qianjiang, 2 in Hechuan, and 1 in Fuling; in other districts and counties, there are 2 in Bishan, 2 in Tongliang, 1 in Dazu, and 1 in Changshou as shown in "Table 8". The district and county distribution of higher vocational colleges and the new urbanization development plan of Chongqing have a consistent aspect, while the economic radiation protection and service functions of higher vocational colleges in other districts and counties to counties can't match imperfectly.

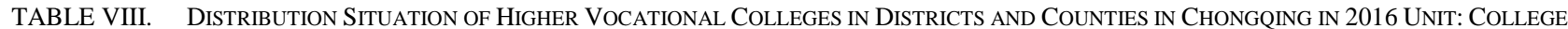

\begin{tabular}{|c|c|c|c|c|c|c|c|c|c|c|c|}
\hline $\begin{array}{l}\text { Districts } \\
\text { And } \\
\text { Counties }\end{array}$ & $\begin{array}{c}\text { Nine } \\
\text { Districts } \\
\text { In The } \\
\text { Main } \\
\text { City }\end{array}$ & Jiangjin & Wanzhou & Yongchuan & Hechuan & Bishan & Tongliang & Qianjiang & Dazu & Fuling & Changshou \\
\hline $\begin{array}{l}\text { Higher } \\
\text { vocational } \\
\text { colleges }\end{array}$ & 16 & 5 & 5 & 4 & 2 & 2 & 2 & 2 & 1 & 1 & 1 \\
\hline
\end{tabular}

2) The unbalanced regional distribution of higher vocational colleges: The centralized distribution of higher vocational colleges restricts the balanced and coordinated development of regional economy. According to the regional distribution of Chongqing higher vocational colleges and the current demand situation of local economic development, it can be found that the difference in regional distribution of colleges is obvious. Colleges are mainly located in the metropolitan area, and mainly concentrated in the urban developed economic circle (totally 16 colleges). The number and quality of higher vocational colleges in northeast Chongqing and southeast Chongqing lag behind the urban developed economic circle (totally 5 and 2 colleges respectively) as shown in "Table 9. It can be found from the comparison of GRP in each region that currently Chongqing higher vocational colleges are concentrated in the region with most dense population and largest GDP contribution.
TABLE IX. COMPARISON OF THE DISTRIBUTION OF HIGHER VOCATIONAL COLLEGES IN CHONGQING AND REGIONAL ECONOMIC DEVELOPMENT IN 2015 UNIT: COLLEGES, 100 MILLION

\begin{tabular}{lll}
\hline \multicolumn{1}{c}{ Region } & $\begin{array}{c}\text { Higher Vocational } \\
\text { Colleges }\end{array}$ & \multicolumn{1}{c}{$\begin{array}{c}\text { Gross Regional } \\
\text { Production }\end{array}$} \\
\hline $\begin{array}{l}\text { metropolitan area } \\
\text { \#developed urban }\end{array}$ & 33 & 12124.03 \\
economic circle & 18 & 6861.01 \\
Northeast Chongqing & 5 & 2720.78 \\
\#Wanzhou district & 5 & 828.22 \\
southeast Chongqing & 2 & 872.46 \\
Qianjinag district & 2 & 202.55 \\
\hline
\end{tabular}

${ }^{1 .}$ Data source: arranged according to the "Table 2-12 sub-regional GDP" of "Chongqing Statistical Yearbook in 2016" and the data of higher vocational colleges published in Chongqing Vocational and Technical Education Online.

Metropolitan area is located in the center of economic, political and cultural development in Chongqing, with various advantages of resources, transportation, and history and so on, and the nine districts in main city lead the economic growth in Chongqing, with strong economic strength and concentrated population distribution. Therefore, a large number of higher vocational colleges choose to distribute in this region, showing a point-like concentrated situation. The natural conditions in the northeast Chongqing and southeast Chongqing are relatively poor, with relatively large pressure of ecological and environmental protection and backward economic and cultural development, so there are 7 higher vocational colleges in 17 districts and counties, 
accounting for $17.5 \%$ of the total number of higher vocational colleges in Chongqing. Objectively, the higher vocational colleges are smaller and have more difficulties in running.

\section{The Combination of Higher Vocational Education with Industry and Enterprises is not Close Enough}

The most important problem in the cooperation between Chongqing vocational colleges and enterprises is the effective docking of school education and business needs is not enough, so a considerable part of the school-enterprise cooperation still remain in the form, and the enthusiasm of depth participation in school-enterprise cooperation of corporate is not high. According to the relevant research data, the higher vocational colleges with the experience of deep school-enterprise cooperation for above 5 years in Chongqing account for $82 \%$, but the higher vocational colleges with $100 \%$ specialty coverage only account for $36.4 \%$. The essential problem is the lack of specific cooperation path and long-term mechanism guarantee. It still needs a process of cultivation and constriction to create a specialty cluster with unique characteristics and core competitiveness of employment. Because of the different interest demand of colleges and enterprises, it is necessary to find the common interests of both sides to solve the problem of asymmetric supply and demand information in the process of personnel training in higher vocational education, to stimulate the enthusiasm of both sides and avoid the phenomenon of "one hot and one cold".

\section{COUNTERMEASURES FOR THE INTEGRATION OF HIGHER VOCATIONAL EDUCATION AND REGIONAL ECONOMIC DEVELOPMENT IN CHONGQING}

Higher vocational education should be efficiently integrated with the regional economic development, and actively promote the structural reform of supply side, proactively adjust the talent supply structure, and focus on training high-end technical and skillful talents that adapt to regional economic cooperation and competition and the development demand of emerging industries to better meet the demand for application-oriented talent of Chongqing economic and social development in the production, management, services and so on.

\section{A. Strengthen Policy Coordination and Effectively Promote School-enterprise Cooperation}

We should further improve the level of mechanism guarantee of school-enterprise cooperation. The government should arrange to establish the leader coordination group of cooperation of production, study, research and application that integrates higher vocational education and technical training composed of the department of education, society, science and technology, and finance, to get rid of barriers, and overall coordinate the sustainable development of higher vocational education; The cooperation of production, study, research and application of higher vocational education should be gradually included in the scope of public financial security, special funds for cooperation of production, study, research and application of higher vocational education should be set up and the long-term protection mechanism and incentive mechanism for public financial input of cooperation of production, study, research and application should be established; preferential tax policy should be formulated for the enterprises that cooperate with higher vocational education in production, study, research and application, and certain economic measures should be adopted to encourage enterprises to participate in the deep cooperation between enterprises and enterprises to cultivate talent and mobilize the enthusiasm of enterprises participation; colleges and enterprises should establish and improve the long-term mechanism of cooperation and connection between enterprises and schools and talent evaluation mechanism for quality of higher vocational education under the guidance of the government and construct the information sharing platform for schoolenterprise cooperation.

Higher vocational colleges should closely dock the backbone enterprises of the industry, use their production facilities and technical strength to cultivate the teachers with dual-teacher quality, implement various forms of schoolenterprise cooperation personnel training model to improve the vocational skills of students; carry out targeted training and employment classes to promote students' employment, and boost the transformation of scientific and technological achievements to application, providing intellectual support for the production of enterprises. In addition, they should also encourage and support industry enterprises and higher vocational institutions to jointly build productive training base, to achieve the sharing of resources including teachers, equipment, and places and other resources, risk and the interests; retired excellent employees of enterprises can also be re-employed to provide technical guidance for cooperating colleges, to promote the training plan of excellent reserve talent of enterprise.

\section{B. Optimize the Specialty Setting to Closely Dock Industrial Structure}

Higher vocational colleges should adhere to the principle of "set specialties according to industrial needs and set courses according to needs of enterprises", and fully listen to the views of enterprises in the specialty setting, curriculum reform, and selection of teaching materials and so on. Specialty setting should be forward-looking, and fully consider the cyclicity of personnel cultivation and marketoriented nature of industrial structure to timely adapt to industrial restructuring.

It is necessary to guide the specialty setting of higher vocational education in Chongqing to incline to the strategic emerging industries like electronic terminal products manufacturing, new material and biological medicine and modern service industry such as logistics, e-commerce and tourism. At the same time, it is also necessary to respond to the "13th Five-Year Plan" of Chongqing, which proposes to transform and improve the traditional manufacturing industry, create a number of characteristic specialty groups, and cultivate more modern high-end technical and skilled talents. Attention should be paid to strengthening the specialty setting related to the development of the focus field 
of primary industry to fill the gaps in the focus specialty setting of primary industry, which can provide personnel support for vigorous development of characteristics and effective agriculture and promotion of the adjustment of agricultural structure; we should also carry out "modern agricultural talent training project", taking the rural surplus labor force or migrant workers who return home to start business as the object by using the principle of proximity to implement the matching between characteristic specialties of higher vocational colleges and the development needs of specific industry in county. The precise pairing support policy should be adopted to train a group of modern agricultural talents to solve the problem of high quality employment of rural labor and promote precision poverty alleviation.

\section{Highlight the Positioning of Colleges and Serve the Balanced Development between Areas}

Based on the main specialty group, the function orientation of higher vocational colleges should be optimized. On the basis of expanding the whole scale of higher vocational colleges, we can combine with the characteristics of regional development to vigorously promote the main specialty of higher vocational college in the metropolitan area to dock the connotation development and upgrading of new technology, new format and new model. The investment in higher vocational education in the northeast Chongqing and southeast Chongqing should be increased in order to support the promotion of connotation, and the establishment of characteristic specialty groups closely related to local social development should be encouraged especially according to the regional function positioning. Moreover, we need to focus on supporting the colleges and universities in the metropolitan area and local higher vocational school to construct the overpass of talents cultivation of "Secondary Vocational Education-higher vocational education-Applied Undergraduate".

Chongqing key industries are encouraged to shift to the northeast Chongqing and southeast Chongqing to promote the demand for local technical and skilled talents. At the same time, more preferential policies should be implemented in various regions to attract the inflow of talents, and under the influence of "agglomeration effect" of industry, domestic and foreign enterprise groups and individuals are encouraged to invest in the above areas to participate in the cooperation in running schools of higher vocational education based on the integrative development of production and education.

\section{Optimize the Investment Mechanism, and Enhance the Overall Development of Higher Vocational Education}

The government's financial investment is the blood of development of higher vocational education, so they should adjust the structure of financial funds, continue to increase the financial support for higher vocational education and further improve the using mechanism of the funds, so as to ensure the rational and efficient use of funds; carry out the private financing for the construction investment in higher vocational colleges, to encourage the trial of joint-stock and cooperative investment school system; allow the higher diversified form of financing of higher vocational colleges and encourage the adoption of BOT, PPP, ABS (assetbacked securities) and asset securitization model and other emerging projects financing methods to solve the problem of funds shortage in the developing process of higher vocational education; through the multi-channel financing or jointly financing of relevant colleges and enterprises, set up Chongqing Vocational Education Investment Guarantee Company by means of shareholding system, to uniformly manage and co-ordinate the problem of funding for vocational education and technical training in Chongqing. Finally, they can optimize the investment, and actively guide to continuously enhance the overall strength of higher vocational education in the region.

\section{CONCLUSION}

To sum up, in terms of external policy orientation and the construction of school culture, the orientation of schoolrunning should be clear. The professional features of the colleges should be distinctive. The colleges should also keep high compatibility with local economic and social development. And the colleges must have strong capability of social service and outstanding industrial advantages. The integration of higher vocational and technical colleges and local industries will enter sustained and sound development.

\section{REFERENCES}

[1] Li Hongxin. Economic mathematical model. South China university of technology press, 2005: 145-155.

[2] Li Xiang, Zhu Yuchun. Gray correlation Analysis of Income and Consumption Structure of Rural Residents. Statistical Research, 2013, 30(1): 76-78.

[3] Xu Ling. An Empirical Study on the Relationship between the Scale of Higher Vocational Education and Economic Growth in China Based on the Data Analysis from 1992 to 2010. Higher Education Exploration, 2013(5):135-138.

[4] Chongqing Municipal People 's Government Opinion of Chongqing Municipal People 's Government on the implementation of the thirteenth five-year plan of Chongqing' $s$ national economic and social development. Gazette of Chongqing Municipal People's Government, 2016(7).

[5] Tan Shaohua. Report on the Questionnaire Survey on School Enterprise Cooperation: http://www.cqzyjy.com/index.php?s=/ articles/1345.html.

[6] Li Hong. On the Relationship between Higher Vocational Education and Regional Economic Development. Petroleum Education, 2005(4): 35-37.

[7] Song Zhengfu. Research on the Development Policy of Higher Vocational Education in Chongqing. Journal of Chongqing Industry \& Trade Polytechnic, 2009(2): 5-14. 